\title{
Meðferð sem forvörn gegn útbreiðslu lifrarbólgu C?
}

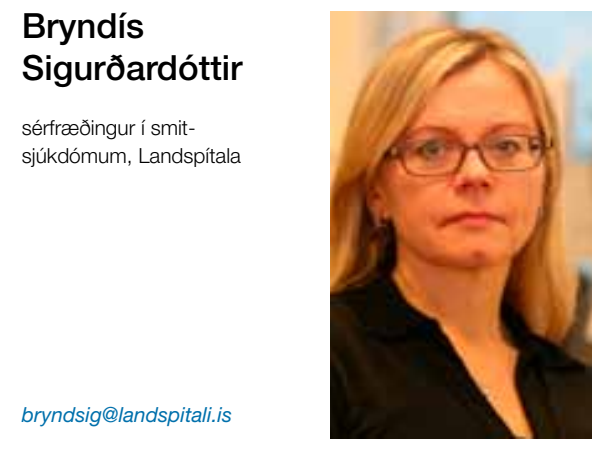

Pau gleðitíðindi bárust almenningi fyrr í pessum mánuði að í samvinnu við lyfjafyrirtækið Gilead muni Íslendingar sem smitaðir eru af lifrarbólgu C-veirunni hafa aðgang að lyfjameðferð sem áður var talin of dýr til að bjóða upp á. Lifrarbólgu Cveiran veldur langvinnri lifrarbólgu hjá um $80 \%$ peirra sem smitast, og getur leitt til skorpulifrar sem aftur er áhættupáttur fyrir krabbameini í lifur. Áhættuhópar eru meðal annars sprautufíklar og einstaklingar sem fengu blóðgjöf fyrir 1992, en pá var farið að skima fyrir lifrarbólgu C-mótefnum hjá blóðgjöfum.

Meðferð með peginterferon og ríbavírín var áður hefðbundin en poldist mjög illa. Sú meðferð er enda orðin úrelt eftir að sýnt hafði verið fram á mun betri líkur á lækningu með notkun svokallaðs direct acting antivirals (DAA), lyfja í töfluformi sem hafa bein áhrif á sértæk ensím veirunnar.

Notkun samsetta lyfsins Harvoni ${ }^{\circledR}$ (ledipasvir-sofusbovir) einu sinni á dag í 8-24 vikur hefur leitt til varanlegrar svörunar (SVR-sustained virological response) í 90-99\% tilfella, hjá sjúklingum með og án skorpulifrar. Рað hefur gífurlega lága aukaverkunartíðni og polist mjög vel sem er algjör bylting frá pví sem áður var. Harvoni ${ }^{\oplus}$ var sampykkt í Evrópu og Bandaríkjunum 2014 og hefur verið í notkun með mjög góðum árangri. Hins vegar er notkun pess forgangsraðað og háð heilsutryggingum og sjúkdómastigun, og ljóst að ekki er verið að meðhöndla nema brot af peim sem myndi gagnast meðferð. Er petta vegna kostnaðar en talið er að einstaklingsmeðferð kosti yfir 60.000 dollara (8 milljónir íslenskra króna).

Meðferðarátakið sem er að hefjast snýst um pað að bjóða öllum hér á landi sem eru með lifrarbólgu C, meðferð með Harvoni ${ }^{\circledR}$. Undirbúningur hefur staðið yfir í tæpt ár, og munu læknar og hjúkrunarfræðingar göngudeilda lifrarsjúkdóma og smitsjúkdóma meðal annars taka pátt í skimun, viðtölum, skoðun og eftirliti sjúklinga. Ljóst er að petta er gífurlega stórt verkefni en talið er að átakið muni ná til 800-1000 manns áður en yfir lýkur. Prátt fyrir bjartsýni er rétt að hafa í huga að vissar hindranir eru á vegi, ef ná á til allra. Stór hluti pessara einstaklinga hefur sögu um neyslu ólöglegra vímuefna og sumir eru enn í virkri neyslu. Samvinna hefur verið með læknum á Sjúkrahúsinu Vogi og fangelsismálayfirvöldum til að undirbúa meðferð peirra einstaklinga sem par eru. Einnig býr töluverður fjöldi pessara einstaklinga við óöruggar aðstæður, ótryggt húsaskjól, fjárhagserfiðleika og undirliggjandi geðsjúkdóma. Ekki má gleyma að heilbrigðiskerfið í heild hefur glímt við niðurskurð og fækkun starfsfólks sem eflaust hefur bitnað á pessum einstaklingum og peirra málefnum.

Starfsmenn göngudeildanna munu afhenda einstaklingum lyf upp á margar milljónir í senn, par sem ein tafla kostar yfir 100.000 krónur. Рað er pví gífurlega mikilvægt að styðja sjúklinga vel til að auka meðferðarheldni, og tryggja sem besta svörun. Ekki er vitað með vissu hversu margir með lifrarbólgu C eru í pessari stöðu, en vissulega má ætla að meðferðarheldni verði ágæt hjá flestum, par sem mikið liggur við að lækning takist.

Göngudeild smitsjúkdóma á Landspítala í Fossvogi hefur reynslu af meðferð einstaklinga með HIV sem eru í virkri neyslu og stunda enn áhættuhegðun. Síðan 2010 höfum við boðið upp á útfærslu af svokallaðri DOT-meðferð (directly observed therapy) sem hefur verið stjórnað af sérfræðingum í hjúkrun. Leiðbeiningar um meðferð HIVsjúklinga hafa breyst og nú er mælt með meðferð allra (sem flestra), óháð hjálparfrumutalningu, einmitt til að koma í veg fyrir útbreiðslu veirunnar (einnig oft nefnt Treatment as Prevention). Pví var pessi leið valin, pað er að bjóða sjúklingum upp á vikulegar komur á göngudeild, jafnvel oftar, til að sækja lítinn skammt í einu af HIVlyfjum. Petta er einnig tækifæri til að hitta hjúkrunarfræðinga og lækna ef parf, spjalla og fá stuðning. Hjúkrunarfræðingar geyma allt að priggja mánaða skammt af lyfjum hvers sjúklings í læstum skáp, og skammta eftir pörfum. Okkar reynsla af pessu hefur verið góð, og pó að pessir aðilar hafi verið í óreglu og hafi lítinn stuðning, hefur meðferðarfylgni verið góð. Mikilvægt er að hafa í huga að pessir einstaklingar finna oft fyrir miklum fordómum pegar peir purfa að leita til heilbrigðispjónustunnar og pví er lögð áhersla á að borin sé virðing fyrir peim og gætt jafnræðis í öllum samskiptum og upplýsingagjöf og pannig reynt að draga úr áhættuhegðun.

Ljóst er að verkefni sem petta mun reyna á innviði heilbrigðiskerfisins, en pað er gífurlega mikilvægt að reyna ná til sem flestra svo að markmið átaksins náist, pað er að útrýma lifrarbólgu $C$ í heilu pjóðfélagi. Рað er pví full ástæða til bjartsýni og verður spennandi að fylgjast með framvindunni.

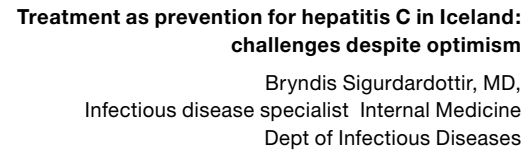

